\title{
New Wave Marketing Dalam Membangun Brand Equity Di Era Digital
}

\author{
Yama Aditya Nugraha dan Umaimah Wahid \\ Program Magister Ilmu Komunikasi Universitas Budi Luhur Jakarta \\ Email:mahamerusenja@gmail.com \\ Email: umaimah.wahid@budiluhur.ac.id
}

\begin{abstract}
The purpose of this research is examine how the establishment of a community of outdoor equipment brand consina in building brand loyalty and how the value of products on the brand of outdoor equipment products consina in building brand awareness. This study uses integrated marketing communication mix. The methodology of this research was applies qualitative approach with case study. The result of this research is the marketing activity of consina always try to align itself with their consumers, it is in accordance with new wave marketing concept where the relationship of a brand with their consumer is horizontal. Consina brand already has a strong character in community that is physical aspect, intellectual aspect, emotional aspect, social aspect, and personality aspect, this impact on the creation of brand awareness among the community, especially among activists of outdoor activities, however for the general public who are not activists of outdoor activities, the level of brand awareness is still in the stage of brand recall. Community management conducted by consina is still not effevtive because brand loyalty formed on brand consina is the result of quality, design, and peice of product from consina brand.
\end{abstract}

Keywords: New Wave Marketing, Brand Value, Brand Equity, digital era consumers

\begin{abstract}
Abstrak
Tujuan dari penelitian ini adalah untuk mengkaji bagaimana New Wave Marketing brand dan Brand Value peralatan outdoor Consina dalam membangun brand loyalty. Penelitian ini menggunakan teori New Wave Marketing. Metode Penelitian ini menggunakan pendekatan kualitatif studi kasus. Hasil penelitian ini adalah pada aktifitas pemasarannya consina selalu berusaha mensejajarkan diri dengan para konsumennya, hal itu sesuai dengan konsep new wave marketing dimana hubungan suatu brand dengan konsumennya bersifat horizontal. Brand consina memiliki karakter yang kuat di masyarakat yaitu aspek fisik, aspek intelektualitas, aspek emosional, aspek, sosial, dan aspek kepribadian, hal ini berdampak pada terciptanya kesadaran merek (brand awarness) di kalangan masyarakat khususnya di kalangan penggiat kegiatan outdoor, Namun, untuk masyarakat umum yang bukan penggiat kegiatan luar ruang, tingkat kesadaran merek masih dalam tahap brand recall (mengingat ulang). Pengelolaan komunitas yang dilakukan oleh consina masih belum efektif karena loyalitas merek (brand loyalty) yang terbentuk pada brand consina merupakan hasil dari kualitas, desain, dan harga produk dari brand consina.
\end{abstract}

Kata Kunci : New Wave Marketing, Brand Value, Konsumen Era Digital 


\section{Pendahuluan}

Perilaku konsumen berubah seiring perubahan dan ketergantungan proses marketing oleh jaringan internet. Era ini menyebabkan khalayak terhubung dan saling berkomunikasi serta membentuk opini, informasi, dan transaksi untuk saling mempengaruhi satu sama lain. Oleh karenanya pemasaran di era digital juga berubah yaitu memudahkan masyarakat/konsumen saling berinteraksi dan terhubung. Perubahan strategi pemasaran mengaharuskan para pemasar harus mengikuti perkembangan teknologi jika ingin memenangkan pasar, karena kalau tidak mengikuti perkembangan teknologi yang ada maka sudah pasti akan kalah dalam persaingan pasar. Hal ini ditunjang dengan kehadiran media baru seperti Blog, Twitter, Facebook, Instagram yang merupakan beberapa aplikasi media social yang berbasis internet yang banyak digunakann oleh masyarakat untuk saling berinteraksi dan menjadi media informasi anyar yang sifatnya interaktif dan viral.

Akibat kompetisi yang lebih besar dan perubahan perilaku konsumen, dunia pemasaran mengalami perubahan signifikan. Persaingan bisa muncul dari mana saja dan dalam bentuk apa saja, sementara konsumen terbuka terhadap informasi yang lebih besar yang muncul dari segala arah. Aturan lama di pasar telah berubah. Dengan demikian, paradigma pemasaran tradisional yang biasa disebuat dengan Legacy Marketing yang dahulu vertikal dan berpusat pada perusahaan juga harus berubah. (Kottler dkk, 2017:48)

Sejalan dengan dengan itu hadir sebuah konsep baru dalam dunia pemasaran, konsep ini dikenal dengan nama konsep New Wave Marketing. konsep ini mencakup strategi dan taktik pemasaran baru untuk mengantarkan nilai optimal kepada konsumen pada era keterhubungan digital. Dalam praktiknya, prinsip - prinsip Legacy Marketing mungkin masih bias diterapkan hingga batas tertentu, tetapi pada saat yang sama perusahaan juga harus mulai mendefinisikan ulang strategi dan taktik pemasaran agar menjadi lebih horizontal pada era new wave ini (Kottler dkk,2017:48).

Di kajian marketing terdahulu, dikenal sembilan elemen terkait dengan pemasaran, seperti segmentasi, targetting, positioning, diferensiasi, marketing-mix, selling, brand, service, dan process. Kesembilan elemen ini berperan sebagai grand design landasan aktivitas bisnis perusahaan. Di era horisontal ini, elemen-elemen itu bergeser. Intinya, pasar tidak lagi menjadi objek, melainkan subjek karena penciptaan nilai pemasaran akan bertambah kalau kita mau melibatkan pelanggannya. Pergeseran itu, misalnya, dari segmentasi ke komunitisasi, targetting ke confirmation, positioning ke clarification, differentiation ke codification. Sementara, bauran marketing 4P (product, price, place, promotion) bergeser menjadi co-creation, currency, communal activation, dan conversation. Selanjutnya, brand menjadi character, service menjadi care, process menjadi collaboration. Semua itu disebut dengan 12C. (http://marketeers.com/mengenal-konsepkonsep-new-wave-marketing/)

Consina merupakan brand peralatan outdoor dari Indonesia. Consina didirikan oleh Disyon Toba. Dyson Toba merupakan pendiri Consina yang lahir pada tahun 1974 dan sekaligus menghobi sebagai pendaki. Kebiasaannya melakukan hobi mendaki gunung membuat ia berfikir untuk membuka usaha dalam bidang peralatan outdoor. Disyon mulai melirik usaha ini pada tahun 1994 yaitu pada tas gunung. Disyon melihat sebuah tas, ia meyakini bahwa tas tersebut merupakan buatan luar negeri.. (http://www.pendaki.info/2016/12/sejarahdidirikannya-consina-oeh-disyon.html) Disyon memberi tau mereka bahwa tas tersebut adalah buatannya, pesananpun mengalir kepada Dyson pada saat itu. Disyon kemudian menyambut pesanan teman - temannya dan kembali mengorder kepada si penjahit tas. Saat itu, Disyon masih belum berfikir untuk memperbesar usaha ini, ia hanya menyanggupi orderan dari teman - temannya dalam jumlah terbatas. Pada tahun 1998, ketika pesanan semakin banyak, Disyon meminta si penjahit untuk membuat tas secara 
reguler. (http://www.pendaki.info/2016/12/ sejarah-didirikannya-consina-oeh-disyon.html)

Produk Consina dipromosi dengan banyak cara agar konsumen menjadi loyal terhadap produknya (Brand Loyalty). Hal dikarenakan banyak bermunculannya produk sejenis yang merupakan saingan utama Consina dalam bidang brand peralatan outdoor contohnya seperti Eiger, dan Cozmedd. Kedua brand ini merupakan saingan utama Consina pada masa sekarang ini. Dalam mengembangkan produknya Consina selalu melibatkan konsumennya. (produk adalah co-creation) Di sini perusahaan memberikan peluang yang sebesar-besarnya kepada konsumen untuk ikut aktif dalam pengembangn produk baru. Artinya produk adalah kreasi bersama antara perusahaan dan konsumennya.

Dalam era digital yang serba terhubung seperti sekarang Consina paham sekali bagaimana cara melakukan kegiatan promosi pemasaran karena konsumen dalam era ini konsumen lebih cerdas dan lebih mudah mendapatkan informasi mengenai produk yang akan mereka beli, strategi pemasaran akan lebih mudah dilakukan apabila suatu brand bisa masuk kedalam media yang dikendalikan dan dimiliki oleh konsumen selain itu suatu brand bisa berinteraksi langsung dengan konsumen. Dalam hal ini Consina tidak hanya melakukan kegiatan pemasaran melalui store, pameran,dll. Consina melakukan kegiatan pemasaran berbasis online, Consina menggunakan media social seperti instagram, facebook, dan twitter, dan juga Consina mempunyai website $w w w$. Consina-adventure.com hal ini dilakukan untuk memberikan informasi kepada konsumennya, baik informasi mengenai produk maupun event atau games yang diselenggarakan oleh Consina,

Kendala yang dihadapi merek-merek produk Outdoor seperti Consina disebabkan segmen mereka yang spesifik yaitu produk mereka ditujukan untuk para penggiat kegiatan luar ruang atau kegiatan outdoor. Pada era digital, informasi tentang suatu produk dapat dengan mudah didapatkan oleh konsumen pada era digital seperti sekarang ini. Mereka dapat saling terhubung baik antar konsumen dan antar produsen brand itu sendiri menggunakan internet. Dengan menggunakan internet konsumen bisa dengan mudah mencari informasi tentang suatu brand, dan juga mempengaruhi loyalitas konsumen akan produk tersebut.hal ini tidak lepas dari tingginya tingkat pengguna internet di Indonesia. menurut lembaga riset pasar e-marketer, populasi pengguna internet pada 2017 diperkirakan mencapai 112 juta orang, mengalahkan jepang di peringkat ke-5 yang pertumbuhan jumlah pengguna internetnya lebih lamban.

(https://kominfo.go.id/content/detail/4286/ pengguna-internet-indonesia-nomor-enamdunia/0/sorotan_media)

Dari latar belakang diatas maka dapat dirumuskan permasalahan sebagai berikut, bagaimana Konsep New Wave Marketing Terkait Brand Value Dalam Membentuk Ekuitas Merek Pada Konsumen Era Digital Pada Brand Peralatan Outdoor CONSINA. Untuk lebih memfokuskan rumusan masalah diatas maka penulis membuat sub pertanyaan adalah:

1. Bagaimana penerapan Konsep New Wave Marketing - komunitas (comunitization brand peralatan outdoor Consina dalam membangun brand loyalty?

2. Bagaimana nilai produk (brand value) pada brand produk peralatan outdoor Consina dalam membangun brand awareness?

Pengertian secara bahasa New Wave Marketing adalah: New artinya Baru, Wave Artinya Gelombang, Marketing Artinya Pemasaran. Namun Istilah New Wave muncul berawal dari kata I Nyoman G. Wiryanata (Direktur Konsumer PT Telkom Indonesia) yang melihat adanya pergeseran-pergeseran dari era ke era selanjutnya. Sehingga Beliau Menyatakan bahwa Era Legacy telah bergeser menjadi era New Wave, Kartajaya (2010:3). Akibat kompetisi yang lebih besar dan perubahan perilaku konsumen, dunia pemasaran mengalami perubahan signifikan. Persaingan bisa mucul dari 
mana saja dan dalam bentuk apa saja, sementara konsumen terbuka terhadap informasi yang lebih besar yang muncul dari segala arah.

Pendekatan dalam paradigma baru ini dikenal dengan sebutan New Wave Marketing. Ini mencakup strategi dan taktik pemasaran baru untuk mengantarkan nilai optimal kepada konsumen pada era keterhubungan digital. Dalam praktiknya, prinsip - prinsip Legacy Maeketing mungkin masih bias diterapkan hingga batas tertentu, tetapi pada saat yang sama perusahaan juga harus mulai mendefinisikan ulang strategi dan taktik pemasaran agar menjadi bih horizontal pada era New Wave ini (Kottler dkk,2017:48) pemetaan karena hal itu terutama memang berurusan dengan pemetaan pasar untuk menentukan segmen. Kotler dkk (2017:168) (Goyat, 2011) menyatakan saat membuat segmentasi, ada beberapa pilihan. Dalam era New Wave, perusahaan harus melakukan communitizatian, yaitu memandang konsumen sebagai sekelompok orang yang saling peduli, mempunyai tujuan bersama, dan berbagi nilai serta identitas. Komunitas bisa dibentuk perusahaan (dengan sengaja) atau sebagai hasil inisiatif konsumen sendiri (tanpa kehadiran perusahaan).

Tabel 2

Perbedaan Legacy Marketing dan New Wave Marketing

\begin{tabular}{|l|l|}
\hline $\begin{array}{l}\text { Legacy Marketing (Pendekatan } \\
\text { pemasaran yang konvensional) }\end{array}$ & $\begin{array}{l}\text { New Wave Marketing (Pendekatan } \\
\text { pemasaran yang terkoneksi) }\end{array}$ \\
\hline - Segmentasi strategis dan positionng & - Konfirmasi ke komuntas konsumen \\
- Diferensiasi dan positioning merek & $\begin{array}{l}\text { Klarifikasi tentang kodifikasi dan karakter } \\
\text { merek }\end{array}$ \\
- Campuran pemasaran taktis (produk, & - Perpaduan pemasaran yang terkoneksi \\
harga,tempat, promosi)danpendekatan & (penciptaan terus menerus, keterbaruan, \\
penjualan & pemanfaatan jaringan / komunitas, \\
- Proses dan layanan yang menciptakan & percakapan) dan komersialisasinya \\
nilai & - Kolaborasi dan kepedulian terhadap \\
& konsumen \\
\hline
\end{tabular}

\section{Sumber : Kotler, Dkk (2017 :49)}

Dari uraian diatas dapat disimpulkan bahwa Konsep New Wave Marketing adalah konsep yang mencakup strategi dan taktik pemasaran baru dengan mengedpankan pendekatan pemasaran yang terkoneksi dan menekankan peran serta melalui keterlibatan konsumen yang lebih dalam dan lebih besar untuk mengantarkan nilai optimal kepada konsumen.

Menurut Kotler dalam kotler dkk (2017:168) Jika diumpamakan bangunan, arsitektur pemasaran terdiri atas tiga pilar utama, yaitu strategi, taktik, dan nilai. Sedangkan dalam New Wave Marketing terdapat perubahan pada unsur di dalam tiga pilar utama tersebut :

\section{Segmentasi adalah Comunitization}

Segmentasi bisa disebut sebagai strategi
(Kotler dkk 2010:170)

\section{Targetting adalah Konfirmasi}

Konsep targeting, biasanya ada tiga kriteria yang harus dipenuhi perusahaan manapun pada saat mengevaluasi dan menentukan segmen mana yang mau dibidik, pertama adalah memastikan bahwa segmen pasar yang dipilih itu cukup besar dan menguntungkan. Kedua targeting ini harus didasarkan pada keunggulan kompetitif. Ketiga segmen pasar yang dibidik itu harus didasarkan pada situasi persaingannya. (Kartajaya, 2010:99-101)

\section{Positioning adalah Konfirmasi}

Kartajaya, (2010:112) menjelaskan 
bahwa di tengah dunia yang berubah dari Legacy ke New Wave, positioning sudah tidak lagi relevan. Positioning adalah praktik yang company-driven, dilakukan untuk membangun persepsi konsumen. Padahal New Wave adalah dunia yang horizontal, dimana konsumen semakin kuat, semakin komunal dan tidak lagi dapat dipaksa untuk membeli. Perusahaan tidak lagi memegang kendali brand nya. Dengan demikian, apa yang harus dilakukan bukanlah positioning lagi, tapi clarification. (Kartajaya, 2010:112)

\section{Diferentiation is Codification (DNA)}

Untuk menang, pemasar harus dapat mengidentifikasi aspek darinya yang betul-betul berbeda sampai ke tingkat DNA, bukan hanya dipermukaan. Differentiation is codification of DNA. Perusahaan juga harus mampu lebih terkoneksi dengan pelanggan sehingga mampu membuat produk yang benarbenar sangat personal bagi pelanggan sehingga tidak satu pun produk lainnya yang menyerupai produk tersebut. (Kartajaya, 2010:112) Kartajaya, (2010:112) menjelaskan bahwadi era New Wave, yang menjadi nyawanya perusahaan adalah codification dari DNA-nya.

\section{Produk adalah Co-Creation}

Proses pengembangan produk tidak lagi dilakukan secara vertikal, namun secara horizontal. Artinya produk adalah kreasi bersama antara perusahaan dan konsumennya. Dalam menerapkan cocreation, ada beberapa hal yang harus dipenuhi. Pertama, identifikasi perilaku konsumen dalam membeli, yang mana secara umum dapat dibagi menjadi dua, yaitu high involvement dan low involvement. Kedua, pilihlah konsumen terbaik yang akan dibatalkan dalam cocreation, atau konsumen yang memiliki kombinasi kriteria konsumen dengan tingkat loyalitas tinggi yang disebut sebagai promoters dan konsumen dengan sifat kreatif dan inovatif yang disebut sebagai innovator (Kartajaya, 2010:132133)

\section{Harga adalah Kurs}

Praktik perusahaan melakukan pricing akan lebih horizontal dengan melewati proses negosiasi dengan pelanggan. Di era Legacy, pemasar dapat bergerak dari price taker menjadi price maker. Kedua, karena adanya Connect! (C kelima), dinamika harga dan biaya akan semakin naik turun secara transparan. Konsumen akan tahu harga yang pas sebetulnya berapa. Ketiga, pemasar menjual produknya yang co-create bersama komunitas pelanggan. (Kartajaya, 2010:142-146)

\section{Tempat adalah Aktivasi Komunal}

Place dalam New Wave Marketing Mix adalah communal Activation. Karena produknya melalui proses Co-create bersama dengan komunitas pelanggan untuk komunitas, sudah lumrah kalau distribusinya lewat komunitas pula. Communal Activation bisa dilakukan selama punya connecting platform yang sifatnya mobile, experential dan juga sosial, yang ada di dunia online dan offline. (Kartajaya, 2010:151-152)

\section{Promosi adalah Percakapan}

Komponen ini menetapkan strategi komunikasi produk dan perusahaan dengan konsumen, (Yusanto dkk, 2003:80) Di era seperti Konsumen juga semakin komunal, saling terhubung di jaringannya dan lebih sosialis. Pada dasarnya mereka juga paham bahwa langkah pemasaran akan lebih mudah apabila ia bisa masuk kedalam media yang dikendalikan dan dimiliki konsumen. (Kartajaya, 2010:165)

\section{Penjualan adalah Komersialisasi} Kartajaya, (2010:176) menjelaskan bahwa setidaknya ada dua kompetensi utama yang harus dimiliki oleh seorang 
salesman di era New Wave ini. Pertama, kemampuan untuk memetakan dan membangun network yang efektif dalam mendukung proses penjualan (mapping and building effective network). Kedua, mengoptimalkan network tersebut untuk mendapatkan penjualan melalui rekomendasi ("commercializing"the network) (Kartajaya, 2010:176)

\section{Brand adalah Character}

Karakter ini adalah isi sesungguhnya ("the true self"). Brand adalah "the cover" atau bungkus. Di era New Wave, positioning adalah pengklarifikasian persona. Pola pikir sebelumnya adalah dalam positioning, kita didorong untuk mengucapkan janji karena positioning adalah bagaimana kita memposisikan diri kita kepada konsumen dan janji tersebut kelak akan ditagih oleh konsumen. Dalam clarification, yang penting bukan janjinya, tapi siapa anda sesungguhnya. (Kartajaya, 2010:188-189)

\section{Service is Care}

Dalam service, perusahaan diharapkan untuk melebihi ekspektasi pelanggan. Dalam care fokusnya adalah memberikan layanan yang paling relevan dengan kebutuhan dan hasrat konsumen. Ini akan menciptakan efek "Wow", yang menjadikan konsumen benar-benar merasa terbantu oleh perusahaan. (Kartajaya, 2010:196-200)

\section{Proses adalah Kolaborasi}

Di dunia pemasaran, proses pada hakikatnya menentukan kualitas (quality), biaya (cost), dan pengiriman produk (delivery) dari perusahaan kepada pelangganya. (Kartajaya, 2010:208). Di era New Wave, aktivitas perusahaan dalam mendesain, membeli, membuat, dan mengirim sebuah barang atau jasa, tentunya akan lebih horizontal karena didukung oleh kekuatan connectivity dari teknologi informasi. (Kartajaya, 2010:208)

Menurut (Kartajaya dkk, 2017:83) konsumen sekarang lebih cerdas dan lebih banyak maunya dibandingkan masa - masa sebelumnya. Teknologi informasi telah menyediakan informasi melimpah bagi mereka, begitu melimpah higga terkadang kosumen memiliki lebih banyak pengetahuan dibandingkan para penjual. Proses pengambilan keputusan oleh konsumen kini dibentuk lama sebelum mereka memasuki toko atau bertemu dengan penjual. Momen baru inilah yang berperan mendorong ratusan juta kali pengambilan keputusan dalam sehari.

Menurut Kartajaya dkk (2017:40-41) pada era keterhubungan, perjalanan konsumen tak lagi langsung dan lurus menyerupai proses berbentuk corong, dan juga tidak bersifat pribadi. Perubahan yang dibawa oleh dunia yang terhubung dan dimotori teknologi menuntut kita untuk mendefinisikan ulang jalur konsumen. Jalur konsumen kini telah berubah lewat proses 5A: Aware (Sadar), Appeal (Daya Tarik), Ask (Permintaan), Act (Tindakan), dan Advocate (Dukungan).

Tabel 3

Jalur Konsumen pada era keterhubungan / digital

\begin{tabular}{|l|l|l|}
\hline $\begin{array}{l}\text { J a I u r } \\
\text { Konsumen }\end{array}$ & Perilaku Pelanggan & Kemungkinan titik sentuh \\
& $\begin{array}{l}\text { Konsumen secara pasif mengungkapkan } \\
\text { berbagai merek yang terkait dengan } \\
\text { pengalaman mereka sebelumnya, komunikasi } \\
\text { Aware } \\
\text { pemasaran, dan atau rekomendasi dari orang } \\
\text { lain }\end{array}$ & $\begin{array}{l}\text { - Mempelajari merek dari } \\
\text { orang lain } \\
\text { Secara tidak sengaja } \\
\text { terekspose pada iklan } \\
\text { suatu merek } \\
- \text { Mengingta pengalaman } \\
\text { yang sudah lalu }\end{array}$ \\
\hline \multirow{3}{*}{ Appeal } & $\begin{array}{l}\text { Konsumen memproses pesan yang } \\
\text { diungkapkan kepada mereka, menciptakan } \\
\text { memori jangka pendek ataupun memperkuat } \\
\text { memri jangka panjang, dan akhirnya hanya } \\
\text { tertarik pada sedikit merek }\end{array}$ & $\begin{array}{l}\text { Menjadi tertarik pada } \\
\text { merek } \\
\text {-Membuat sederet merek } \\
\text { untuk dipertimbangkan }\end{array}$ \\
\hline
\end{tabular}




\begin{tabular}{|c|c|c|}
\hline Ask & $\begin{array}{l}\text { Didorong oleh rasa penasaran, para konsumen } \\
\text { secara aktif mencari informasi lebih banyak } \\
\text { tentang merek yang diminati dari teman-teman } \\
\text { dan keluarga, dari media, dan atau langsung } \\
\text { dari perusahaan sendiri. }\end{array}$ & $\begin{array}{l}\text { - Menghubungi teman } \\
\text { untuk meminta saran } \\
\text { - Mencari ulasan produk } \\
\text { di internet } \\
\text {-Menghubungi call center } \\
\text {-M e m b a n d i n g k a n } \\
\text { harganya produknya } \\
\text {-Mencoba langsung di took }\end{array}$ \\
\hline Act & $\begin{array}{l}\text { Setelah dibekali lebih banyak informasi, } \\
\text { konsumen membeli produk dan layanan } \\
\text { merek tertentu dan berinteraksi lebih jauh } \\
\text { dengan merek tersebut melalui pembelian, } \\
\text { penggunaan, dan atau proses layanan }\end{array}$ & $\begin{array}{l}\text { - Beli di took atau online } \\
\text { menggunakan produk } \\
\text { untuk kali pertama } \\
\text { - Mengeluh saat produk } \\
\text { bermasalah } \\
\text { - Mendapatkan layanan } \\
\text { perbaikan }\end{array}$ \\
\hline Advocate & $\begin{array}{l}\text { Seiring berjalannya waktu, para konsumen } \\
\text { mungkin mengembangkan rasa kesetiaan yang } \\
\text { kuat terhadap sebuah merek, yang awalnya } \\
\text { tercermin dari ingatan, pembelia ulang dan } \\
\text { akhirnya rekomendasi kepada orang lain }\end{array}$ & $\begin{array}{l}\text { - Tetap menggunakan } \\
\text { merek itu } \\
\text { - Membeli produk merek } \\
\text { itu lagi } \\
\text { - Merekomendasikan } \\
\text { merek itu kepada orang } \\
\text { lain }\end{array}$ \\
\hline
\end{tabular}

Sumber : Kartajaya dkk, (2017:43)

\section{Metode Penelitian}

Dalam penelitian ini, penulis menggunakan paradigma konstruktivis. Menurut Creswell (2010:12) paradigma kontruktivisme adalah cara pandang yang mendekatkan pada pemahaman terhadap makna yang beragam sebagai hasil dari konstruksi sosial. Metode penelitan yang digunakan adalah studi kasus. Menurut Robert K. Yin (2004:1) Studi kasus merupakan strategi yang lebih cocok bila pokok pertanyaan suatu penelitian berkaitan dengan how atau why. Tipe desain studi kasus yang digunakan dalam penelitian ini adalah Desain Kasus Tunggal dengan Multi Level Analysis. Penelitian ini memfokuskan kepada suatu brand Consina dalam menggunakan Konsep New Wave Marketing dalam membangun Ekuitas Merek Pada Konsumen Era Digital.

Key informan dan beberpa informan yang menjadi nara sumber dalam penelitian. Teknik wawancara dengan mengkonfirmasi data yang diperoleh dari informan/narasumber dengan data yang ada di lapangan, melihat secara lanngsung (abservasi) kondisi yang sebenarnya terjadi di lapangan melalui observasi dan pengamatan langsung.

Berikut identitas nama informan pokok (key informan) yaitu :

1. Paulus Tirta. Merupakan Promotion Coordinator dari Consina.

2. Disyon Toba. Merupakan direktur dari consina the outdoor lifestyle,

3. Andika Pradipta. Bagian promosi dari consina, beliau bertugas mendesign, menetapkan, dan mengatur segala baik melalui media cetak, media elektronik, dan media social.

4. Indra Pratama. Seorang karyawan 
swasta, pemakai produk consina mulai tahun 2004 hingga sekarang.

5. Evan Pratama. Seorang karyawan swasta, beliau mempunyai hobi kegiatan luar ruang atau kegiatan outdoor, salah satu pemakai produk consina mulai tahun 2000 hingga sekarang.

6. Muslih. seorang online marketer dari ARA Outdoor Equipment, aktif di komunitas backpacker Jakarta dan komunitas saya consiners.

7. Deco Bangun. Mahasiwa universitas Mercu Buana bekasi, aktif di komunitas Backpacker Jakarta.

Lokasi penelitian adalah di Kantor pusat dan warehouse ConsinaKota Bekasi, Jawa Barat 17151 dan Consina Store Tebet. Waktu penelitian selama 5 bulan yaitu bulan Juli 2017 sampai dengan November 2017.

\section{Hasil Penelitian dan Pembahasan}

Consina merupakan brand peralatan outdoor dari Indonesia. Disyon Toba pada tahun 1999 merasa pada saat itu produk lokal dalam bidang kegiatan outdoor di Indonesia memerlukan pemain baru yang mempunyai kualitas bagi penggunanya ditengah maraknya produk outdoor yang berasal dari luar negri. Dyson Toba merupakan penggiat kegiatan outdoor yang sudah berpengalaman dalam bidang pendakian gunung baik gunung di Indonesia maupun di luar negri seperti Cartenz pyramid, kalapathar dan Himalaya.

Sampai tahun 2015 seluruh produk Consina yang terdiri dari tas, backpacks, pakaian, sandal, sepatu, outdoor living gear, dan juga alat safety climbing. Produk Consina dapat diakses melalui www.consina-adventure.com. Hingga kini, Consina sudah memiliki 500 mesin jahit dengan 700 karyawan. Omsetnya mencapai Rp. 5 miliar hingga Rp. 15 miliar sebulan. Bahkan toko agen Consina mencapai 200 toko gerai.

\section{Product Positioning}

Consina mendistribusikan dan menjual secara langsung. Pada tahun 2017 Consina mempunyai 46 toko yang berlokasi di bebarapa kota besar di Indonesia. Dengan mempunyai took-toko yang tersebar di Indonesia konsumen akan lebih mudah mendapatkan atau membeli produk Consina. Unique saling prepositioning Consina adalah produk peralatan outdoor yang terjangkau untuk semua kalangan.

\section{Identifikasi Produk Consina}

Produk Consina merupakan produk yang digunakan untuk kegiatan outdoor seperti mendaki, arung jeram, panjat tebing, bersepeda, aksesoris, apparel, backpack, dll. Namun demikian produk Consina juga bisa digunakan untuk kegiatan sehari-hari seperti bekerja, kuliah, maupun sekolah. Sesuai dengan taglinenya "The Outdoor Lifestyle" Consina berusaha menciptakan trend outdoor yang bisa dipakai para penggiat kegiatan luar ruang tetapi juga bisa dipakai untuk kegiatan sehari-hari seperti ke kantor, sekolah, kuliah, dan lainnya. Keunggulan Consina dari sisi desain produk sudah diakui konsumen. Produk dari Brand consina meliputi :

\section{Backpack}

Backpack adalah tas yang dipakai dipunggung, backpack pada brand consina meliputi daypack, bodypack, carrier, notebook backpack dan duffles

\section{Aksesoris}

Pada produk dari brand consina, aksesoris adalah alat pendukung dalam kegiatan outdoor

\section{Apparel}

Apparel dari produk consina adalah busana yang dipakai untuk kegiatan outdoor tetapi juga bisa dipakai dalam kegiatan sehari-hari, apparel dari produk consina meliputi jaket, celana, t-shirt, kemeja, dll

\section{Outdoor Living}

Produk Outdoor Living pada consina adalah alat penunjang dalam melakukan kegiatan outdoor seperti tenda, climbing safety, alat masak, dll 


\section{Pengembangan Produk dari Brand Consina}

Agar kualitas produk tetap terjaga, consina juga selalu mengembangkan produknya, dalam hal pengembangan produknya, consina mempunyai bagian research and development yang bisa input info trend dunia outdoor baik itu trend global maupun trend lokal, consina juga melibatkan para professional dalam pengembangan produknya, selain itu consina juga selalu melibatkan konsumennya, hal itu diungkapkan oleh bapak Paulus Tirta

Kita masih berusaha untuk capai ke satu struktur organisasi dimana $R n D$ (research and Development) itu jalan, dia bisa getter input dari mana saja dari tren global, tren local, kemudian feedback dari professional untuk barang-barang yang bersifat technical, sedangkan untuk barang-barang yang bukan bersifat technical yaitu seperti backpack, itu dapat feedback dari teman-teman sales, karena mereka yang tahu tentang kebutuhan produk di satu daerah. Dan juga customer juga bisa dilibatkan dalam bentuk focuss grup (Wawancara tanggal 17 November 2017 Pukul 09.30 WIB)

Dalam pengembangan produknya consina melibatkan konsumennya dengan cara mengajak para pecinta produk consina yang disebut "consiners" dalam mereview produkproduk consina dan untuk selanjutnya hasil review tersebut dapat dijadikan acuan untuk pengembangan produk kedepannya, hal itu dikatakan oleh bapak Andika Pradipta selaku bagian promosi dan sponsorship

selain survey kita juga punya komunitas kita nyebutnya "consiners" jadi para pecinta produk-produk consina kita sering ajak kumpul di Buaran jadi kita disitulah kita review bareng jadi bentuknya sih talkshow jadi misalnya temanya pertemuan sekarang temanya apa masih soal pendakian terus disitu kita ada komunikasi " ni ada tas baru kita menurut kalian gimana?" nah itu seru tuh apa namanya tektokannya "ah kurang ini bang, kurang ini bang, bagusnya untuk nextnya kaya gini aja bang ininya tasnya” kaya gitu-gitu, jadi itu padahal kita itu ga dibayar mereka yang ikhlas rela datang sendiri ke toko buat kasih pendapat apa segala macem ya kita suka banget kita terbuka banget toko gitu. Makanya toko buaran itu mau kita design sedemikian rupa juga jadi kaya basecamp jadi tempat ngumpul gitu ga cuma toko jual barang, bayar transaksi terus pulang gitu enggak gitu. (wawancara tanggal 27 November 2017 pukul 16.00)

\section{Pembahasan}

\section{New Wave Marketing dan Ekuitas Merek di Era Digital}

New Wave Marketing adalah konsep yang mencakup strategi dan taktik pemasaran dengan mengedepankan pemasaran yang terkoneksi dan peran serta melalui keterlibatan konsumen yang lebih dalam untuk mengantarkan nilai optimal kepada konsumen. New wave marketing adalah perpaduan pemasaran yang terkoneksi yang menempatkan brand sejajar dengan konsumennya.

Dalam melakukakan marketing-nya Consina menempatkan brand produk sejajar dengan konsumen. Consina tidak menempatkan brand produk diatas konsumen. Ekuitas merek yang terbentuk terlihat dari brand awareness dan brand loyalty. Brand Value dapat menciptakan kesadaran merek (brand awareness) kepada masyarakat juga menjadi faktor utama dalam membentuk brand loyalty.

Consina dalam melakukan strategi pemasaran berusaha menciptakan dan mengkomunikasikan nilai, agar terbentuk hubungan yang kuat antara merek dengan konsumennya. Dalam mengkomunikasikan nilai yang terkandung dalam produk, Consina melakukannya secara online maupun offline.

Pada era digital konsep pemasaran 
harus berubah menjadi lebih horizontal. Merek atau brand harus sejajar dengan konsumen dikarenakan perilaku konsumen sudah berubah. Pada era digital keputusan pembelian konsumen sangat dipengaruhi oleh lingkungan sekitar karena arus informasi yang sangat cepat dan kemudahan untuk berinteraksi antar masyarakat dapat dengan mudah dilakukan. Hal ini berpengaruh kepada persepsi brand di tengah masyarakat.

Apabila pandangan konsumen terhadap nilai brand itu baik tentunya akan berdampak kepada penerimaan di masyarakat. Sistem komunikasi pada era digital berlangsung secara online, para konsumen dapat langsung mengakses informasi dan menyebarkan informasi dari suatu produk dari brand yang mereka pakai secara cepat.

Strategi pemasaran yang dilakukan Consina terbukti dapat menciptakan ekuitas merek. Consina menerapkan konsep new wave marketing yaitu pengelolaan komunitas agar dapat menciptakan brand loyalty dan juga menerapkan branding berkarakter dalam membangun brand awareness.

\section{Comunitization Brand dan Brand Loyalty}

Pada era digital keputusan pembelian konsumen sangat dipengaruhi oleh lingkungan sekitar karena arus informasi yang sangat cepat dan kemudahan untuk berinteraksi antar masyarakat dapat dengan mudah dilakukan. Hal ini berpengaruh kepada persepsi brand di tengah masyarakat. Sistem komunikasi pada era digital berlangsung secara online, para konsumen dapat langsung mengakses informasi dan menyebarkan informasi dari suatu produk dari brand yang mereka pakai secara cepat.

Para penggiat kegiatan outdoor biasanya melakukan kegiatannya secara individu maupun berkelompok. Dengan berkelompok para penggiat dapat memakai produk secara berkelompok, antara lain seperti tenda, flysheet, kompor untuk berkemah, dll, selain itu mereka juga dapat saling bertukar informasi mengenai produk-produk outdoor baik dari sisi kualitasnya, modelnya, dan harganya.

Consina mendukung komunitas dengan tujuan sebagai sarana interaksi, sarana dialog dalam menciptakan dan memelihara hubungan antara konsumen dan brand produk. Dalam hal mengelola komunitas Consina aktif mengajak konsumennya untuk melakukan kegiatan bersama, melakukan pendakian bersama, mensponsori acara suatu komunitas, dan membuat kegiatan pelatihan untuk komunitas. Mereka membuat event yang ditujukan untuk komunitas penggiat kegiatan luar ruang seperti JAMCONAS (Jambore Consina Nasional).

Pada konsep new wave marketing segmentasi itu menjadi communitization. Hubungan yang terjadi antara brand Consina dengan konsumen bersifat horizontal dengan tujuan mengidentifikasi komunitas yang potensial berdasarkan keterikatan dan pengaruh dari brand Consina.

\section{Nilai Produk dan Brand Awareness}

Konsep new wave marketing yang dilakukan oleh brand Consina terkait brand value dalam membangun brand awareness. Hal ini terlihat dari upaya brand Consina untuk menciptakan karakter terhadap produk, menjadi indicator nilai brand dalam membangun kesadaran merek. Pada konsep new wave marketing, brand dibangun agar mempunyai karisma yang memberikan pengaruh kuat. Hal ini dilakukan karena pada era digital seperti sekarang pola perilaku konsumen berubah, karena akibat percepatan dalam arus informasi. Menurut Kartajaya (2017:151) pada masa ketika teknologi informasi masih terbatas, keputusan pembelian konsumen didorong lebih secara individual dan sulit dipengaruhi konsumen lain, kecuali oleh keluarga dekat dan teman-teman.

Jalur konsumen bergerak melalui proses 4A: Aware, Attitude, dan Act Again. Namun, pada era New Wave, jalur konsumen berubah menjadi 5A: Aware, Ask, Act, dan Advocate. Konsumen pada era digital dalam membuat keputusan lebih cenderung melibatkan konsumen lain, dan aktif bertanya mengenai nilai suatu produk. Mereka 
juga mendukung produk yang mereka pakai dan untuk selanjutnya menyampaikan nilai produk tidak lagi kepada orang-orang terdekat, tetapi juga kepada kelompok lain yang lebih besar.

Untuk membangun karisma yang memberikan pengaruh kuat suatu brand untuk itulah diperlukan konsep branding berkarakter. Konsep branding berkarakter merupakan kombinasi dari model WOW Leadership (Kartajaya \& Ridwansyah, 2014) dan dikombinasikan dengan tiga kunci kemenangan dari era new wave. Keenam aspek WOW Leadership untuk membangun karisma internal pemimpin mencakup fisik, intelektual, emosional, sosial, keperibadian, dan kemampuan moral.

Tiga kunci kemenangan itu (i) mengombinasikan pendekatan online dan offline, (ii) menciptakan gaya dengan substansi, dan (iii) menggunakan mekanisme mesin ke mesin (M2M) untuk memperoleh hubungan emosional manusia ke manusia (H2H). Dengan pendekatan branding berkarakter, konsumen bertindak lebih sebagai pengikut, mengikuti merek, memilih diantara sekian banyak pesaing lain, dan bahkan membelanya dengan sukarela karena karisma merek tersebut.

\section{Fisik}

Produk Consina sudah sangat dikenal baik kalangan masyarakat penggiat kegiatan outdoor ataupun masyarakat umum. Kesadaran merek (brand awareness) cukup tinggi di kalangan penggiat kegiatan luar ruang. Namun, untuk masyarakat umum, tingkat kesadaran merek masih dalam tahap brand recall (mengigat ulang). Produk Consina dikenal mempunyai karakter yaitu berupa desain dan paduan warna dengan harga produk terjangkau bagi semua kalangan. Dari daya tahan dan kenyamanan produk, Consina masih kalah dibandingkan produk yang berasal dari luar negeri. Karakter inilah yang membuat Consina mempunyai tingkat kesadaran merek yang tinggi.

Hal ini sesuai dengan konsep kepemimpinan merek pada konsep new wave marketing, yaitu konsep branding berkarakter. Konsep branding berkarakter. Sesuai dengan tagline yaitu "The Outdoor Lifestyle", disini Consina berusaha merubah image dan fungsi produk outdoor, fungsi itu dirubah, Consina menciptakan produk yang bisa dipakai untuk kegiatan. Consina berusaha menciptaka trend outdoor di kalangan masyarakat.

\section{Intelektualitas}

Intelektualitas menjadi satu aspek penting, karena merek harus mengamati tren yang berubah dan tidak statis. Merek harus dapat beradaptasi dan menangkap peluang baru dan mengadopsinya ke dalam sebuah produk. Dalam melakukan promosinya Consina menggunakan unsur dalam bauran komunikasi pemasaran yaitu direct marketing. Dalam hal ini Consina melakukan strategi pemasaran langsung melalui dua jalur yaitu baik online maupun offline.

Pembentukan brand awareness sangat terbantu oleh oleh trend digital dan trend visual. Media sosial sangat membantu dalam menyampaikan informasi event, diskon, dan pembukaan store baru. Trend digital juga berpengaruh pada saluran distribusi produk. Consina menempatkan produknya di 3 marketplace besar di Indonesia yaitu bukalapak, tokopedia dan lazada. Selain online jalur distribusi produk dilakukan secara offline. Store fisik masih dirasa perlu, karena dalam pasar outdoor konsumen masih sering datang ke toko. Mereka datang untuk menguji langsung kualitas produk karena dalam kegiatan outdoor kualitas produk menjadi hal yang sangat krusial. 


\section{Emosional}

Kartajaya (2017:201) mengatakan bahwa era new wave mendorong perusahaan untuk lebih cerdas dalam menemukan kombinasi yang tepat dari pendekatan online-offline, khususnya untuk konsumen yang berubah menjadi semakin komunal, berkat perubahan dari segmentasi menjadi communitization. Oleh karena itu, perusahaan pada level taktis juga perlu menerapkan inisiatifyang tepat., salah satunya lewat pemanfaatan komunitas yang sejajar dengan saluran distribusi perusahaan, dalam hal tujuan, nilai, dan identitas. Inilah yang disebut aktivasi komunal.

\section{Sosial}

Strategi promosi yang dilakukan oleh Consina dengan memanfaatkan platform online berupa media sosial dan marketplace yang ada di Indonesia disamping sebagai sarana untuk mempromosikan produk tetapi juga sebagai sarana interaksi serta untuk memperluas penyebaran produk. Merek harus dapat memfasilitasi hubungan para konsumen. Pada era digital, teknologi memnungkinkan interaksi menjadi lebih mudah, karena pada era digital ini terdapat banyak aplikasi yang memudahkan masyarakat untuk berinteraksi satu sama lain, salah satunya media sosial. Dari media sosial, Consina dapat berinteraksi dengan para konsumennya. Hal ini yang mendorong consina untuk membuat suatu komunitas yang bertujuan memfasilitasi konsumen yang loyal terhadap produk consina. Consina menyebut para konsumennya dengan consiners, hal itu tidak lepas dari banyaknya permintaan konsumen yang loyal akan produk consina. Aspek sosial juga jelas terlihat pada event Consina yaitu JAMCONAS (Jambore Consina Nasional)

\section{Kepribadian}

Dalam melakukan kegiatan pemasarannya, Consina tidak hanya mengejar keuntungan semata, tetapi juga menanamkan nilai berupa edukasi kepada konsumennya. Misi itu berupa kampanye pelestarian alam seperti go green, save the earth, dll. dalam konsep new wave marketing kepribadian merupakan salah satu aspek dalam membentuk merek yang berkarakter, karena dengan karakteristik merek yang menunjukan bahwa suatu brand atau merek dilahirkan bukan sekedar mengejar profit semata, tetapi juga mempunyai misi positif yang berpengaruh baik terhadap masyarakat maupun lingkungan sekitar.

Dari 6 aspek konsep branding berkarakter, Consina memiliki 5 aspek yaitu fisik, intelektualitas, emosional, sosial, kepribadian dan kepribadian. Brand Consina sudah cukup dikenal di kalangan penggiat kegiatan outdoor, untuk masyarakat umum yang bukan penggiat kegiatan luar ruang, tingkat kesadaran merek masih dalam tahap brand recall. Dalam aktifitas pemasaran Consina juga masih menggunakan aspek yang terdapat pada bauran komunikasi pemasaran diantaranya advertising, promotional selling, direct marketing dan event.

\section{Simpulan}

Berdasarkan hasil peneliitian dan pembahasan, dapat disimpulkan bahwa ada beberapa hal mengenai konsep new wave marketing terkait brand value dalam membangun ekuitas merek pada konsumen era digital

1. Produk dari Brand peralatan Consina mempunyai karakter yang sangat berbeda dengan produk outdoor lainnya yaitu berupa desain produk yang multifungsi, warna produk Consina yang berani mengkombinasikan produk outdoor dengan warna-warna cerah. Harga produk Consina terjangkau untuk semua kalangan walaupun segmentasi pasar Consina untuk kalangan 
menengah keatas. Consina mempunyai 2 saluran distribusi yang membuat produk dapat mudah ditemukan oleh masyarakat.

2. Kelemahan Consina terlihat dari sisi kenyamanan produk, untuk segmen pasar lokal, namun bila dibandingkan dengan produk dari brand impor, Consina tidak bisa bersaing dari kenyamanan produk.

3. Perkembangan teknologi pada era digital ini dapat menjadi peluang, karena Consina dapat dengan cepat dan mudah memberikan informasi kepada konsumen.

4. Ancaman bagi brand peralatan outdoor Consina datang dari pesaing dalam segmen produk outdoor, perilaku konsumen pada era digital karena pada era digital yang serba terhubung, konsumen dapat dengan cepat mendapat dan menyebarkan informasi mengenai kualitas suatu produk yang dapat mempengaruhi konsumen lainnya.

\section{Saran}

Saran untuk peneliti selanjutnya dengan memperbaiki kekurangan ataupun keterbatasan yang ada dalam penelitian ini yaitu meneliti dengan menggunakan konsep new wave marketing. Selain peneliti selanjutnya sebaiknya dapat melakukan penelitian pada subjek penelitian yang berbeda dengan menyajikan data-data yang lebih lengkap.Sedangkan Saran Praktis bagi pengembangan produk Consina adalah (1) Memaksimalkan saluran distribusi baik via online maupun offline. Hal ini dilakukan agar produk dari brand consina dapat dengan mudah dijangkau oleh masyarakat, (2) Memaksimalkan promosi secara online dan offline. Promosi yang dilakukan secara online sangat efektif karena dapat dengan cepat mentransfer informasi mengenai produk dari brand consina, selain itu konsumen juga dapat dengan mudah mendapatkan informasi. (3) Membuat kegiatan atau event sebagai bentuk pengabdian masyarakat. (4) Membuat event atau kegiatan yang melibatkan masyarakat umum, saat ini consina sedang mengejar pangsa pasar masyarakat yang bukan penggiat kegiatan alam bebas, tentunya consina harus bisa masuk di tengah-tengah mereka, contoh kegiatan atau event yang bisa consina lakukan dalam berbagai bentuk kegiatan, (5) Menjaga kualitas produk, brand consina sudah sangat dikenal di kalangan masyarakat dalam hal desain dan harganya yang terjangkau untuk kalangan masyarakat, tentunya hal ini harus tetap ditingkatkan dan dijaga karena banyaknya persaingan dari brand dalam sector brand peralatan outdoor, (6) Memaksimalkan strategi pengelolaan komunitas, pengelolaan komunitas menurut penelitan diatas belumlah maksimal, dikarenakan para konsumen loyal akan produk consina lebih dari sisi kualitas produk dan harga, untuk itu perlu ditingkatkan lagi dalam hal pengelolaan komunitas.

\section{Daftar Pustaka}

A.Shimp Terence, 2000, Periklanan Promosi Aspek Tambahan Komunikasi

Pemasaran Terpadu. Terjemahan oleh : Revyani Sjahrial, S.E dan Dyah Anikasari, S.Sos. Jakarta: Erlangga Aaker, DavidA. 1997. Manajemen Ekuitas Merek: Memanfaatkan Nilai dari Suatu Merek. Cetakan Pertama. Mitra Utama: Jakarta.

Amstrong, G \& Kotler P. 1997. Prinsipprinsip pemasaran, cetakan pertama. Erlangga: Jakarta.

Amstrong, Gary \& Philip, Kotler. 2002. Dasardasar Pemasaran. Jilid 1, Alih Bahasa Alexander Sindoro dan Benyamin Molan. Penerbit Prenhalindo: Jakarta.

Bilson, Simamora. 2001. Memenangkan Pasar dengan Pemasaran Efektif dan Profitabel. Edisi pertama. PT. Gramedia Pustaka Utama: Jakarta.

Boone, Louis E. Kurtz, David L. 2008. Pengantar Bisnis Kontemporer, buku 1. Salemba Empat: Jakarta. Creswell, John W. .2010. Research Design Pendekatan Kualitatif, Kuantitatif, dan Mixed. Pustaka Pelajar: Yogyakarta.

Dewi, Janita Ike. 2005. Perspektif Baru dalam Strategi Branding, Bisnis, dan Karir. Penerbit Amara Books: Yogyakarta. 
Kartajaya, Hermawan., dan Waizly Darwin. 2010. CONNECT!SurfingNewWaveMarketing. Gramedia Pustaka Utama: Jakarta.

Kotler, Philip dan Gary Amstrong. 2012 Prinsip -Prinsip Pemasaran. Edisi 13. Jilid 1. Erlangga. Jakarta. Buchari, Alma. Manajemen Pemasaran \& Pemasaran Jasa. CV. Alfabeta. 2007: Bandung.

Kotler, Philip, dan Kevin Lane Keller. 2009. Manajemen Pemasaran Jilid 1, Edisi Ketiga Belas. Erlangga: Jakarta. 2017.

Manajemen Pemasaran Buku 2, Edisi Ketiga Belas. Erlangga: Jakarta. Kotler, Philip, Hermawan Kartajaya dan Hooi Don Huan. 2017. Marketing For Competitiveness, Asia Yang Mendunia Di Era Konsumen Digital. Bentang Pustaka: Jakarta. Kotler, Philip; Armstrong, Garry, 2008. Prinsip-prinsip Pemasaran, Jilid 1, Erlangga: Jakarta. Rangkuti, Freddy.2014. Analisis SWOT: Teknik Membedah Kasus Bisnis. Gramedia: Jakarta

Schiffman dan Kanuk. 2008. Perilaku konsumen. Edisi 7. Indeks: Jakarta.

Shimp, Terence A. 2003. Periklanan Promosi Aspek Tambahan Komunikasi Pemasaran Terpadu. : Erlangga: Jakarta.

Stanton J, William. 2005. Prinsip Pemasaran, Jilid I (Edisi ke 7): Jakarta

WilliamLawranceNeuman,2003.SocialResearch Methods: Qualitative and Quantitative Approaches. Pearson Education: USA

Yin, Robert K. 2004. Studi Kasus (Desain dan Metode), RajagrafindoPersada: Jakarta.

Sumber Tesis dan Jurnal Penelitian Ilman Fachrian Fadli, 2010. Analisis Customer Based Brand Equity (CBBE) Hasil dari program Integrated Marketing Communication (IMC) Dalam membangun ekuitas merek (Studi Kasus: LA lights). Universitas Indonesia Jakarta Resti Lusan Nugrahaini, Nunuk Adiarni dan
Mudatsir Najamuddin, 2014. Analisis Penguatan Merek Dalam Membentuk Ekuitas Merek Pada Minuman Sari Buah BB (Studi Kasus: Mahasiswa (end user). Fakultas Sains dan Teknologi) UIN Syarif Hidayatullah Jakarta Santy Tri Widyaningrum, 2012. Analisis Ekuitas Merek (Brand Equity) Melalui Komunikasi Pemasaran Terpadu (Integrated Marketing Communications - IMC) Pada PT. Nasmoco Majapahit Semarang. FISIP Universitas Diponegoro Semarang Ratih Tresnati. 2005. Pemasaran Bagi Petualang Sebagai Kegiatan Komunikasi Pemasaran.

\section{Internet}

http://inibangsaku.com/Consina-peralatanOutdoor-kenamaan-indonesia/

(http://id.wikipedia.org/wiki/Asam deoksiribonukleat, (di akses tanggal 9 Juni 2017 pukul 10 WIB)

http://hawarimuhtarom.blogspot.co.id/2016/11/ makalah-tantangan-era-digital.html (diakses pada 5 juli 2017 pukul 11.00 WIB)

http://ConsinaAdventure.com (diakses pada 5 juli 2017 pukul 10.30 WIB)

(www.topbrand.com/faq diakses pada 21 Agustus pukul 00.45 WIB)

( h t t p s: // m an sarke 13. wordpress . com/2016/02/03/4p-marketing-mix-of-produkConsina/ diakses pada 20 Agustus 2017 pukul 20.31 WIB)

(http://indopreneurship.com/brand/capaisukses-inilah-4-resep-brand-Consina-untukkuasai-pasar-dan-konsumen/ diakses pada 20 Agustus 2017 pukul 08.50 WIB)

(https://kominfo.go.id/content/detail/4286/ pengguna-internet-indonesia-nomor-enamdunia/0/sorotan_media, diakses pada 21 Agustus 2015 pukul $10.15 \mathrm{WIB}$ ) 